\title{
APLIKASI PENJADWALAN MATA KULIAH MENGGUNAKAN ALGORITMA PARTICLE SWARM OPTIMIZATION (PSO)
}

\author{
Irfrans Kusmarna ${ }^{1}$, Luh Kesuma Wardhani ${ }^{2}$, Muhammad Safrizal ${ }^{3}$ \\ 1,3Jurusan Teknik Informatika, Fakultas Sains dan Teknologi, UIN Sultan Syarif Kasim Riau \\ ${ }^{2}$ Prodi Teknik Informatika, Fakultas Sains dan Teknologi, UIN Syarif Hidayatullah Jakarta \\ ${ }^{1}$ irfranstif@gmail.com, ${ }^{2}$ luhkesuma@uinjkt.ac.id, ${ }^{3}$ safrizal.ilal@ gmail.com
}

\begin{abstract}
ABSTRAK
Tujuan dari penelitian ini adalah untuk membangun aplikasi penjadwalan kuliah menggunakan algoritma Particle Swarm Optimization (PSO). Algoritma ini dipilih sebagai algoritma yang digunakan dalam penelitian ini karena algoritma PSO yang merupakan algoritma heuristik, adalah salah satu metode optimasi yang menggabungkan localsearch dan global search. Algoritma ini dapat memecahkan masalah dengan membentuk partikel-partikel pada populasi awal secara acak, mengevaluasi nilai fitness, dan meng-update velocity serta posisi dari partikel. Dengan demikian diharapkan output yang dihasilkan merupakan kombinasi terbaik dari serangkaian komponen yang ada. Kasus penjadwalan yang digunakan pada penelitian ini adalah penjadwalan mata kuliah di UIN Sultan Syarif Kasim Riau (UIN SUSKA). Permasalahan yang terjadi pada penjadwalan mata kuliah di UIN SUSKA Riau adalah tidak optimalnya pemenuhan beberapa contraint seperti keterbatasan ruangan. Dari hasil pengujian, aplikasi penjadwalan perkuliahan meggunakan algoritma PSO mampu menghasilkan jadwal perkuliahan yang sudah tidak ada bentrok tetapi masih tidak memenuhi dari segi kualitas yaitu jam dimulainya perkuliahan inti yang difokuskan pada jam-jam yang efektif.
\end{abstract}

Kata kunci: Constraint, Fitness, Particle swarm optimizaton, Penjadwalan

\section{PENDAHULUAN}

Penjadwalan merupakan proses, cara, pembagian waktu berdasarkan rencana pengaturan yang terperinci. Terdapat banyak hal yang harus dijadwalkan di suatu perguruan tinggi, di antaranya proses penerimaan mahasiswa baru, seminar, Ujian Tengah Semester (UTS), Ujian Akhir Semester (UAS), dan yang paling penting yaitu penjadwalan mata kuliah. Penjadwalan mata kuliah merupakan hal yang penting di dunia pendidikan. Penjadwalan yang baik dan memenuhi semua ketentuan universitas dan jurusan merupakan salah satu hal yang menjamin kelancaran pelaksanaan kegiatan belajar mengajar.

Permasalahan penjadwalan juga terjadi di UIN Sultan Syarif Kasim (Suska) Riau. Berdasarkan hasil wawancara yang dilakukan oleh peneliti dengan Sekretaris Jurusan Teknik Informatika UIN Suska Riau, terdapat beberapa aturan yang harus diperhatikan pada saat penjadwalan mata kuliah di Jurusan Teknik Informatika (TIF) UIN Suska Riau, yaitu:

a) Setiap mata kuliah disajikan maksimal 2 (dua) kali sehari;

b) Setiap dosen dijadwalkan mengajar 2 (dua) kali sehari; c) Tidak terdapat perkuliahan pada jam shalat Jumat;

d) Tidak terdapat perkuliahan pada jam makan siang;

e) Mata kuliah inti informatika dijadwalkan pagi hari;

f) Dosen praktisi dijadwalkan mengajar hari sabtu;

g) Dosen TIF dan non-TIF dijadwalkan mengajar pada hari senin-jumat.

h) Mata kuliah pilihan dijadwalkan siang hari;

i) Tidak ada perkuliahan pada hari Kamis dari pukul 08.00-12.00 bagi mahasiswa semester I, II, dan III;

j) Waktu perkuliahan yang tersedia adalah hari SeninRabu adalah antara pukul 08.00-16.00 WIB, dan hari Kamis-Jumat antara pukul 08.00-16.30 WIB.

Untuk menyelesaikan masalah tersebut digunakan algoritma Particle Swarm Optimization (PSO). Algoritma ini dapat memecahkan masalah dengan membentuk partikel-partikel pada populasi awal secara acak, mengevaluasi nilai fitness, dan mengupdatevelocity serta posisi dari partikel berdasarkan ruang pencarian.

Diharapkan dengan bantuan Particle Swarm Optimization (PSO) penyusunan penjadwalan mata kuliah dapat dioptimalkan.Rumusan masalah dari penelitian ini adalah,"Bagaimana membangun aplikasi penjadwalan dengan menggunakan Particle Swarm Optimization(PSO)pada Jurusan Teknik Informatika 
UIN Suska Riau”. Sedangkan batasan masalah dalam penelitian ini adalah:

1. Mata kuliah yang akan mengalami proses dalam Particle Swarm Optimization (PSO) hanya mata kuliah yang sifatnya memerlukan ruangan, hari dan waktu tertentu.

2. Constraint yang digunakan bersifat statis yang diinputkan pada program.

3. Constraint mengikuti aturan yang berlaku pada penyusunan jadwal kuliah di jurusan teknik informatika UIN Suska Riau.

\section{TINJAUAN PUSTAKA}

\subsection{Penjadwalan Kuliah}

Menurut Putra (2009)[2], penjadwalan merupakan proses untuk menyusun suatu jadwal atau urutan proses yang diperlukan dalam sebuah persoalan. Persoalan penjadwalan biasanya berhubungan dengan penjadwalan kelas dalam sekolah atau perkuliahan dan juga dalam lingkup yang tidak jauh berbeda seperti penjadwalan ujian, penjadwalan karyawan, ataupun penjadwalan job shop. Dalam penjadwalan kuliah, akan dibahas tentang pembagian jadwal untuk tiap mahasiswa pada kuliah tertentu sekaligus dosen pengajarnya. Dalam penjadwalan ujian akan dibahas pengaturan dosen yang menjaga ujian dan mahasiswa yang menempati ruang ujian yang ada.

a. Mendefinisikan atau membuat model dari permasalahan. Model yang dibuat mencakup proses apa saja yang akan dikerjakan dalam persoalan penjadwalan yang ada.

b. Mendesain metode penyelesaian untuk permasalahan penjadwalan tersebut. Dari model yang telah ada, ditentukan metode yang digunakan untuk menyelesaikan permasalahan penjadwalan tersebut.

c. Mencari bermacam-macam contoh permasalahan penjadwalan yang telah dibuat. Dalam proses ini dilakukan pencarian penyelesaian penjadwalan yang pernah digunakan agar dapat dipakai sebagai referensi dalam proses yang sedang dilakukan.

\subsection{Particle Swarm Optimization (PSO)}

PSO, merupakan algoritma berbasis populasi yang mengeksploitasi individu dalam pencarian. Dalam PSO populasi disebut swarm dan individu disebut particle. Tiap partikel berpindah dengan kecepatan yang diadaptasi dari daerah pencarian dan menyimpannya sebagai posisi terbaik yang pernah dicapai. Algoritma PSO ini awalnya diusulkan oleh J. Kennedy dan R. C. Eberhart.

PSO didasarkan pada perilaku sosial sekawanan burung atau sekumpulan ikan. Algoritma PSO meniru perilaku sosial organisme ini. Perilaku sosial terdiri dari tindakan individu dan pengaruh dari individuindividu lain dalam suatu kelompok. Kata partikel menunjukkan, misalnya, seekor burung dalam kawanan burung. Setiap individu atau partikel berperilaku secara terdistribusi dengan cara menggunakan kecerdasannya (intelligence) sendiri dan juga dipengaruhi perilaku kelompok kolektifnya. Dengan demikian, jika satu partikel atau seekor burung menemukan jalan yang tepat atau pendek menuju ke sumber makanan, sisa kelompok yang lain juga akan dapat segera mengikuti jalan tersebut meskipun lokasi mereka jauh di kelompok tersebut.

Algoritma PSO terdiri dari tiga tahap[1], yaitu pembangkitan posisi serta kecepatan partikel, update velocity (update kecepatan), updateposition (update posisi).

Pertama posisidan kecepatandari kumpulan partikel dibangkitkan secara random menggunakan batas atas $\left(x_{\max }\right)$ dan batas bawah $\left(x_{\min }\right)$ dari design variable, seperti yang ditunjukkan pada persamaan (1) dan (2) (3):

$$
\begin{gathered}
x_{0}^{i}=x_{\min }+\operatorname{rand}\left(x_{\max }-x_{\min }\right) \\
v_{0}^{i}=x_{\min }+\operatorname{rand}\left(x_{\max }-x_{\min }\right)
\end{gathered}
$$

Dimana:

$$
\begin{aligned}
x_{0}^{i} & =\text { posisi awal } \\
v_{0}^{i} & =\text { kecepatan awal } \\
x_{\min } & =\text { batas bawah } \\
x_{\max } & =\text { batas atas } \\
\text { rand } & =\text { nilai } \text { random antara nilai } 0 \text { dan } 1
\end{aligned}
$$

Dalam proses random diperlukan slot untuk menampung dari random posisi dan random kecepatan. Melalui proses pembangkitan partikel ini dapat maka kumpulan partikel dapatterdistribusi secara acak. Posisi dan kecepatan dari partikel direpresentasikan melalui vector.

$v_{k+1}^{i} v_{k}^{i} p_{k}^{g}$ Langkah kedua adalah update velocity (kecepatan) untuk semua partikel pada waktu $k+1$ menggunakan fungsi objektif atau nilai fitness [4] posisi partikel saat ini pada design space saat waktu ke $k$. Dari nilai fitness dapat ditentukan partikel mana yang memiliki nilai global terbaik (global best) pada swarm saat ini, dan juga dapat ditentukan posisi terbaik dari tiap partikel pada semua waktu yang sekarang dan sebelumnya $\left(p^{i}\right)$. Perumusan update velocity menggunakan dua informasi tersebut untuk semua partikel pada kumpulan dengan pengaruh perpindahan yang sekaranguntuk memberikan arah pencarian untuk generasi selanjutnya.

Perumusan updatevelocity mencakup beberapa parameter random ( $r a n d$ ), untuk mendapatkan cakupan 
yang baik pada design space, tiga parameter yang mempengaruhi arah pencarian, yaitu inertia factor $(w)$, self confidence $\left(\mathrm{c}_{1}\right)$, swarmconfidence $\left(\mathrm{c}_{2}\right)$ akan digabungkan dalam satu penyajian, seperti yang ditunjukkan persamaan berikut:

$$
v_{\mathrm{k}+1}^{\mathrm{i}}=w^{*} v_{\mathrm{k}}^{\mathrm{i}}+\mathrm{c}_{1} * \operatorname{rand}^{*}\left(p^{\mathrm{i}}-x_{\mathrm{k}}^{\mathrm{i}}\right)+\mathrm{c}_{2} * \operatorname{rand}^{*}\left(p_{\mathrm{k}}^{\mathrm{g}}-x_{k}^{i}\right)
$$

Dengan range $w=0.4-0.9$, rand=interval 0-1,

Langkah terakhir dari setiap iterasi adalah update posisi tiap partikel dengan vektor velocity, seperti yang ditunjukkan pada persamaan berikut:

$$
x_{k+1}^{i}=x_{k}^{i}+v_{k+1}^{i}
$$

Tiga tahapan di atas akan diulang sampai krtiteria kekonvergenan terpenuhi, kriteria kekonvergenan sangat penting dalam menghindari penambahan fungsi evaluasi setelah solusi optimum didapatkan, namun kriteria kekonvergenan tidak selalu mutlak diperlukan, penetapan jumlah iterasi maksimal juga dapat digunakan sebagai stopping condition dari algoritma.

Banyak cara untuk membangun kondisi berhenti, di antaranya adalah: iterasi dihentikan ketika PSO telah mencapai iterasi maksimum, atau PSO telah menemukan nilai optimum tertentu atau kesalahan minimum yang diinginkan.

Algoritma PSO adalah sebagai berikut:

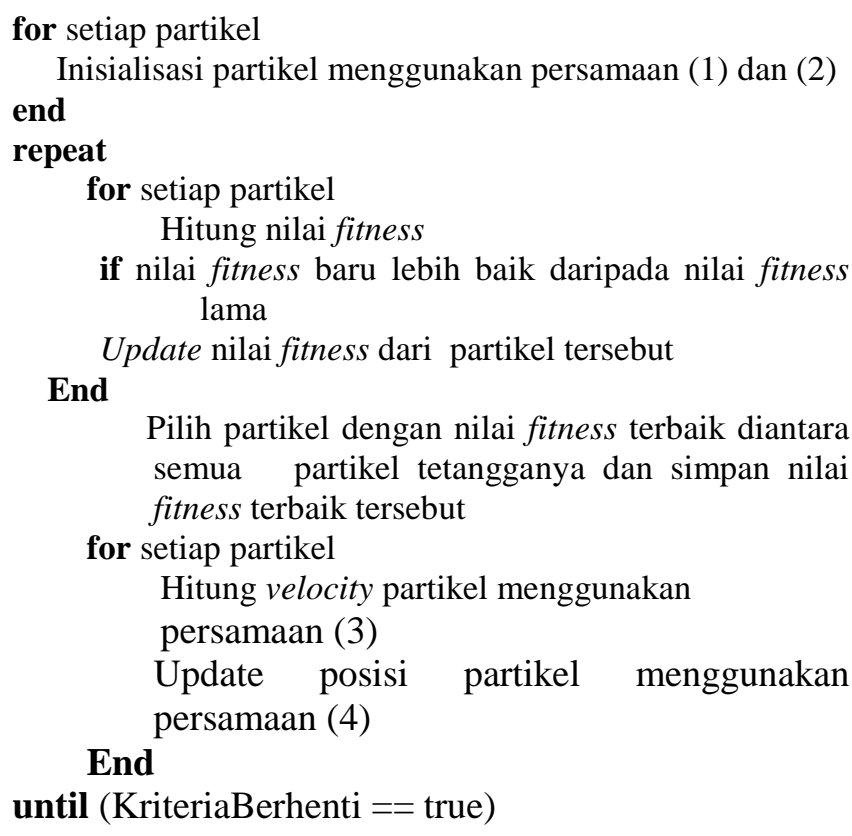

Pilih partikel dengan nilai fitness terbaik diantara semua partikel tetangganya dan simpan nilai fitness terbaik tersebut

for setiap partikel

Hitung velocity partikel menggunakan

persamaan (3)

Update posisi partikel menggunakan persamaan (4)

End

until (KriteriaBerhenti $==$ true $)$

\section{ANALISA DAN PERANCANGAN}

\subsection{Aturan Penjadwalan Kuliah}

Aturan-aturan penjadwalan di Jurusan Teknik

Informatika UIN Suska Riau adalah sebagai berikut:

1. Ruangan kelas tidak boleh dijadwalkan lebih dari satu perkuliahan secara bersamaan.

2. Perkuliahan mahasiswa tidak boleh dijadwalkan secara bersamaan.

3. Dosen tidak boleh dijadwalkan mengajar secara bersamaan.

4. Setiap mata kuliah disajikan maksimal 2 (dua) kali sehari.

5. Setiap dosen dijadwalkan mengajar 2 (dua) kali sehari.

6. Tidak terdapat perkuliahan pada jam shalat jumat.

7. Tidak terdapat perkuliahan pada jam makan siang.

8. Mata kuliah inti dijadwalkan pagi hari.

9. Dosen praktisi dijadwalkan mengajar hari Sabtu.

10. Dosen TIF dan non-TIF dijadwalkan mengajar pada hari senin-jumat.

11. Mata kuliah pilihan dijadwalkan siang hari.

12. Tidak ada perkuliahan pada hari Kamis dari pukul 08.00-12.00 bagi mahasiswa semester I, II, dan III.

13. Waktu perkuliahan yang tersedia adalah hari Senin-Rabu adalah antara pukul 08.00-16.00 WIB, dan hari Kamis-Jumat antara pukul 08.0016.30 WIB.

\subsection{Analisa PSO Pada Kasus Penjadwalan Mata Kuliah}

Gambar 1 adalah diagram alir analisa PSO dalam penjadwalan mata kuliah di jurusan TIF UIN SUSKA Riau. 


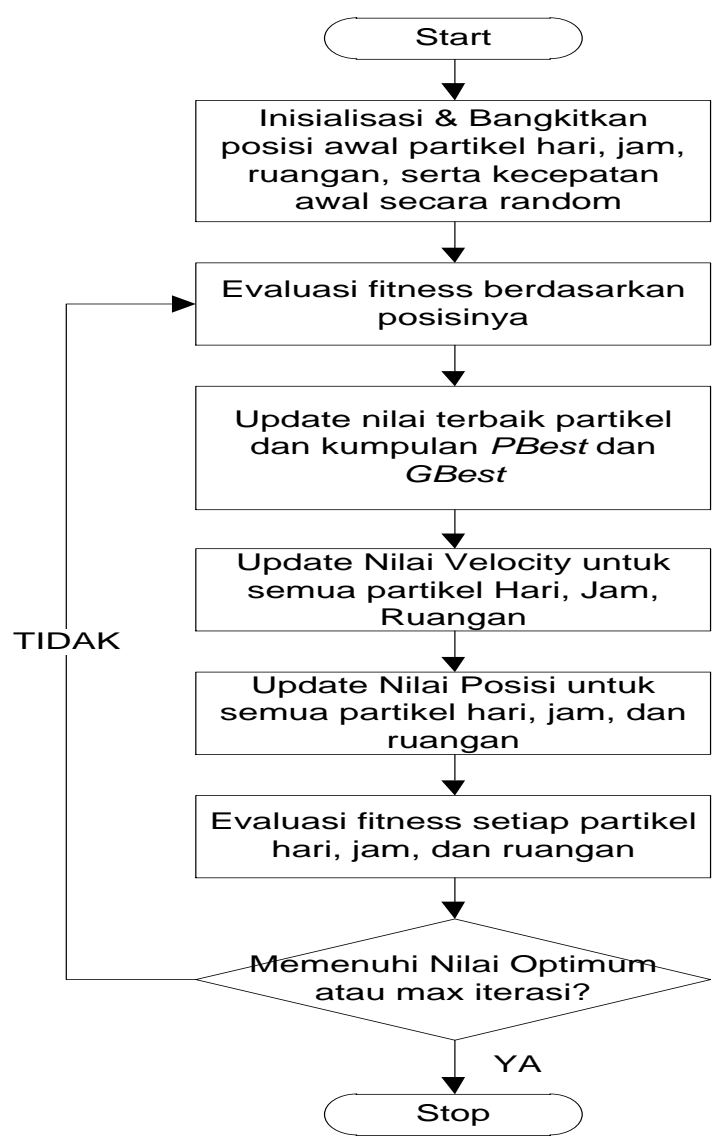

Gambar 1. Diagram alir analisa PSO dalam penjadwalan mata kuliah

Partikel yang diinisialisasi dalam penjadwalan mata kuliah ini meliputi data jam, ruang, hari, dosen, mata kuliah, dan ajar.

Tabel 1 Inisialisasi Data Jam

\begin{tabular}{|c|c|}
\hline Id_Jam & Jam \\
\hline 1 & $08.00-08.50$ \\
\hline 2 & $08.50-09.40$ \\
\hline 3 & $09.40-10.30$ \\
\hline 4 & $10.30-11.20$ \\
\hline 5 & $11.20-12.10$ \\
\hline 6 & $13.00-13.50$ \\
\hline 7 & $13.50-14.40$ \\
\hline 8 & $14.40-15.30$ \\
\hline 9 & $15.30-16.20$ \\
\hline
\end{tabular}

Tabel 2Inisialisasi Data Ruangan

\begin{tabular}{|c|c|}
\hline Id_Ruangan & Nama Ruangan \\
\hline 1 & TIF 301 \\
\hline 2 & TIF 302 \\
\hline 3 & TIF 303 \\
\hline 4 & TIF 304 \\
\hline 5 & TIF 305 \\
\hline 6 & PSI 101 \\
\hline 7 & PSI 102 \\
\hline 8 & PSI 103 \\
\hline 9 & LAB 1 \\
\hline 10 & LAB 2 \\
\hline
\end{tabular}

Tabel 3.Contoh Pembangkitan posisi partikel pada iterasi pertama

\begin{tabular}{|c|c|c|c|c|c|c|}
\hline \multicolumn{4}{|c|}{ Partikel 1} & $\begin{array}{c}\text { Partikel } \\
2 \\
\end{array}$ & $\begin{array}{c}\text { Partike } \\
13 \\
\end{array}$ & $\begin{array}{c}\text { Partikel } \\
4\end{array}$ \\
\hline \multicolumn{4}{|c|}{ Ajar } & \multirow[b]{2}{*}{ Hari } & \multirow[b]{2}{*}{ Jam } & \multirow{2}{*}{$\underset{n}{\text { Ruanga }}$} \\
\hline Id & MK & Dosen & $\begin{array}{c}\text { Kela } \\
\text { s }\end{array}$ & & & \\
\hline 1 & 1 & 26 & A & 1,1 & 8,1 & 3 \\
\hline 2 & 1 & 26 & B & 2,6 & 4,6 & 4 \\
\hline 3 & 1 & 26 & $\mathrm{C}$ & 2,1 & 4,6 & 4,5 \\
\hline 4 & 1 & 25 & $\mathrm{D}$ & 2,8 & 6,4 & 5,2 \\
\hline
\end{tabular}

Update velocity dan posisi menggunakan parameter uji coba yang diambil dari hasil penelitian yang dilakukan oleh Dian Ariani (Ariani, 2011) yang mana dengan parameter ini dapat menghasilkan ratarata jadwal yang lebih optimal. Nilai tersebut adalah: $\mathrm{C} 1=1.5 ; \mathrm{C} 2=1.5 ; \mathrm{w}=0.5$.

Contoh hasil perhitungan update velocity dan posisi pada iterasi pertama dapat dilihat pada tabel 4 .

Tabel 4. Contoh Hasil perhitungan update velocity dan posisi pada iterasi pertama

\begin{tabular}{|c|c|c|c|c|c|c|c|c|}
\hline \multicolumn{4}{|c|}{ Partikel } & \multirow{3}{*}{$\mathbf{R} \mathbf{1}$} & \multirow{3}{*}{$\mathbf{R 2}$} & P2 & P3 & P4 \\
\hline \multicolumn{4}{|c|}{ Ajar } & & & \multirow{2}{*}{ Hari } & \multirow{2}{*}{ Jam } & \multirow{2}{*}{ Ruangan } \\
\hline Id & Makul & Dosen & Kelas & & & & & \\
\hline 1 & 1 & 26 & $\mathrm{~A}$ & 0.3 & 0.2 & 1.7 & 12.2 & 4.5 \\
\hline 2 & 1 & 26 & B & 0.3 & 0.4 & 3.9 & 6.9 & 6.0 \\
\hline 3 & 1 & 26 & $\mathrm{C}$ & 0.1 & 0.2 & 3.2 & 4.9 & 7.8 \\
\hline 4 & 1 & 25 & $\mathrm{D}$ & 0.1 & 0.3 & 4.2 & 9.6 & 7.8 \\
\hline
\end{tabular}

Langkah selanjutnya adalah hitung kembali nilai fitness. Jika posisi semua partikel menuju ke satu nilai yang sama, maka ini disebut konvergen. Jika belum konvergen maka langkah 2 diulang dengan memperbaharui iterasi $i=i+1$, dengan cara 
menghitung nilai baru dari $p^{i}$ dan $p_{k}^{g}$. Proses iterasi ini dilanjutkan sampai semua partikel menuju ke satu titik solusi yang sama. Biasanya akan ditentukan dengan kriteria penghentian (stopping condition), misalnya jumlah selisih solusi sekarang dengan solusi sebelumnya sudah sangat kecil.

\subsection{Fungsi}

Fungsi-fungsi yang dibutuhkan oleh sistem adalah sebagai berikut:

1. Fungsi Pembangkitan Posisi dan Kecepatan Fungsi ini digunakan untuk inisialisasi dan pembuatan populasi awal dengan mengacak semua data ajar, data ruangan, data hari, dan data jam menjadi partikel-partikel
2. Fungsi Fitness

Fungsi yang digunakan untuk menyatakan seberapa baik nilai dari suatu individu ataupun solusi yang didapatkan.

3. Fungsi Update Kecepatan

Fungsi ini digunakan untuk memperbarui nilai kecepatan berdasarkan nilai fungsi yang diberikan.

4. Fungsi Update Posisi

Fungsi ini digunakan untuk memperbarui nilai posisi baru partikel berdasarkan nilai kecepatan perpindahan partikel.

5. Fungsi Setting (Pengaturan)

Dalam fungsi ini tedapat fasilitas untuk menentukan parameter-parameter dalam PSO, seperti nilai faktor inertia, learning rates (self confidence, swarmconfidence). Akan tetapi parameter ini juga memiliki nilai default untuk mengantisipasi bila perubahan nilai parameter menghasilkan kinerja yang kurang memuaskan.

\subsection{Diagram Alir Sistem}

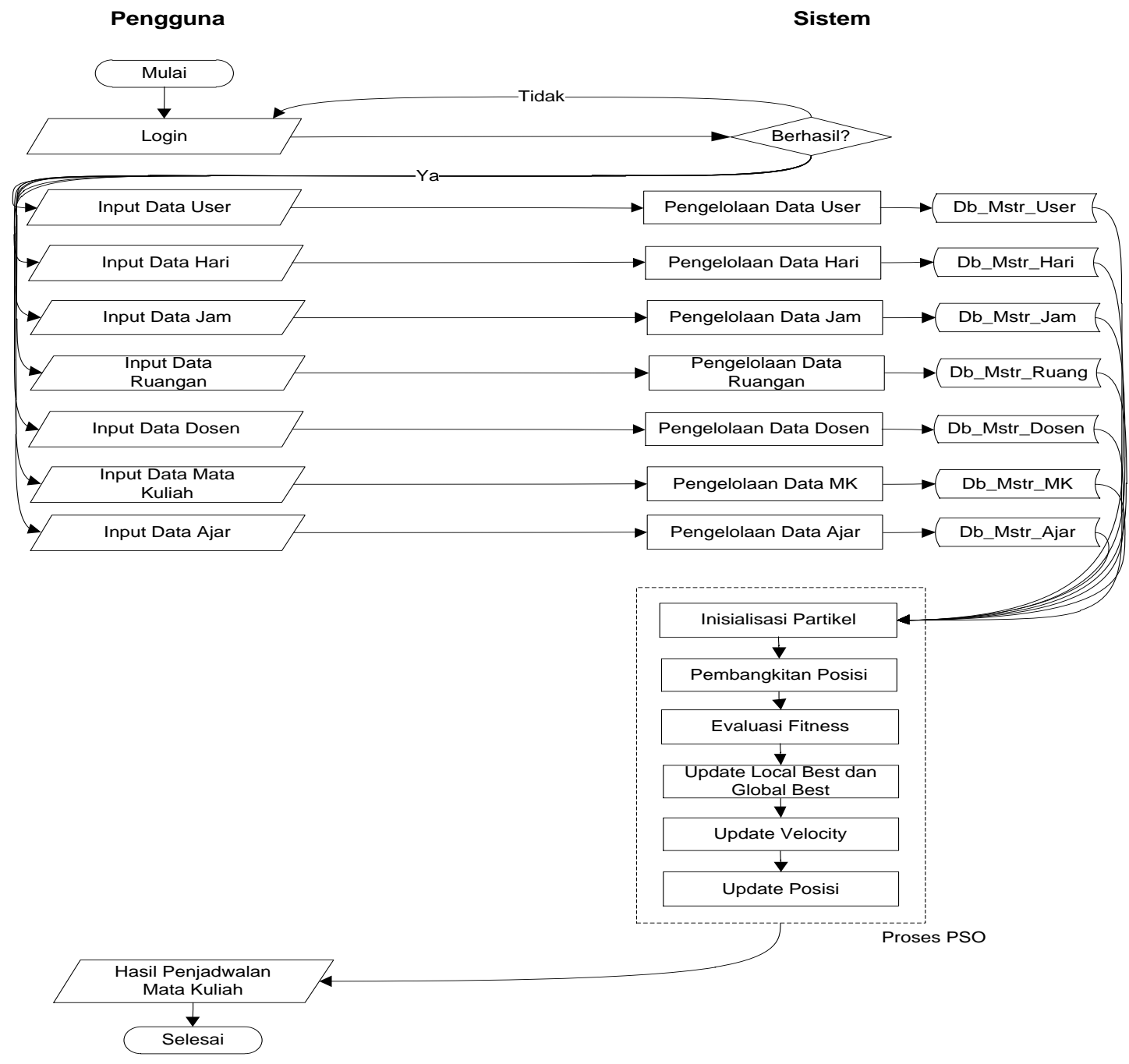

Gambar 2. Diagram Alir Sistem 


\subsection{Entity Relationship Diagram (ERD)}

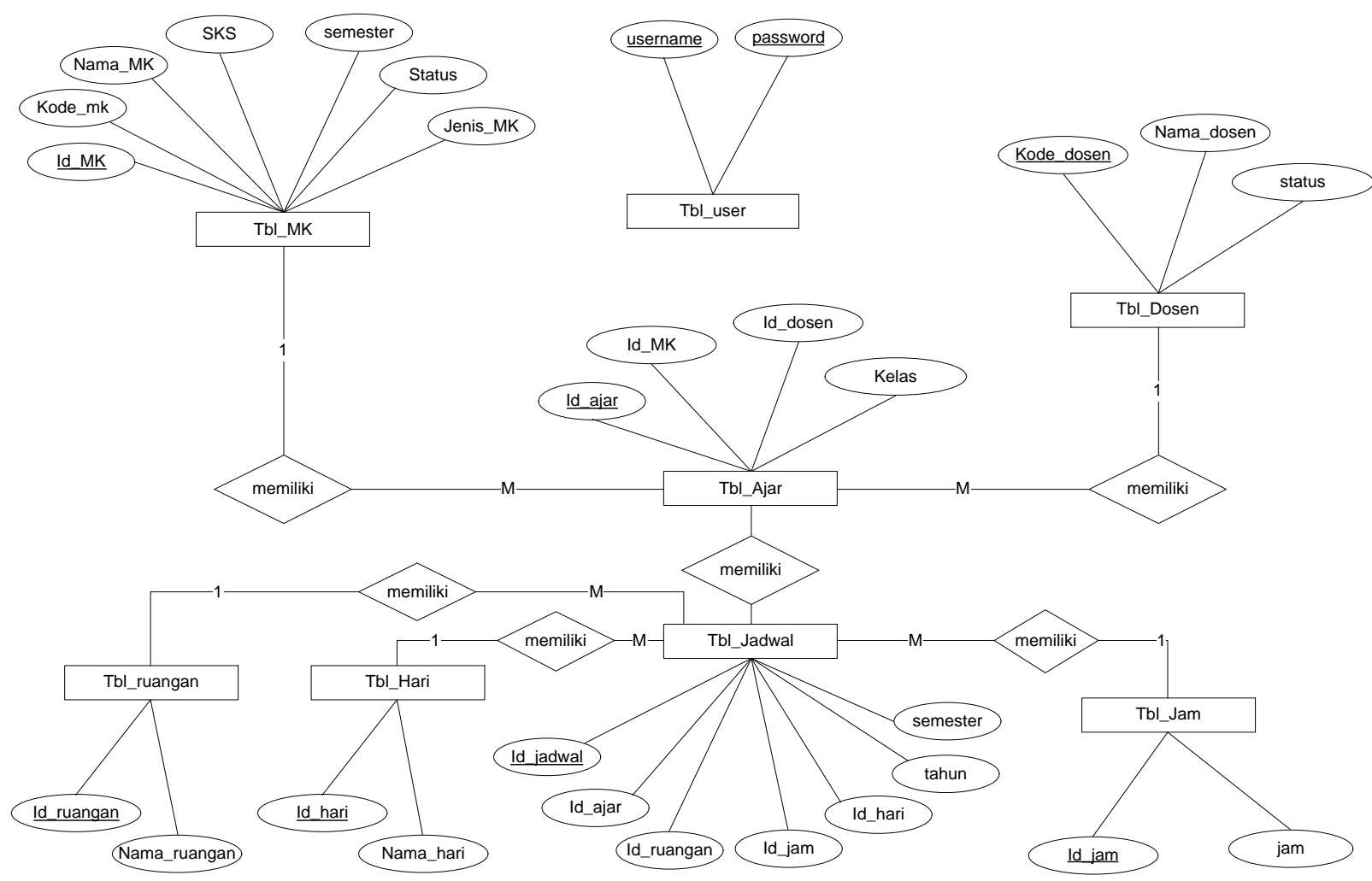

Gambar 3. Entity Relationship Diagram (ERD)

\section{IMPLEMENTASI DAN PENGUJIAN}

\subsection{Implementasi}

Tampilan menu utamadapat diakses jika menu login dinyatakan valid.

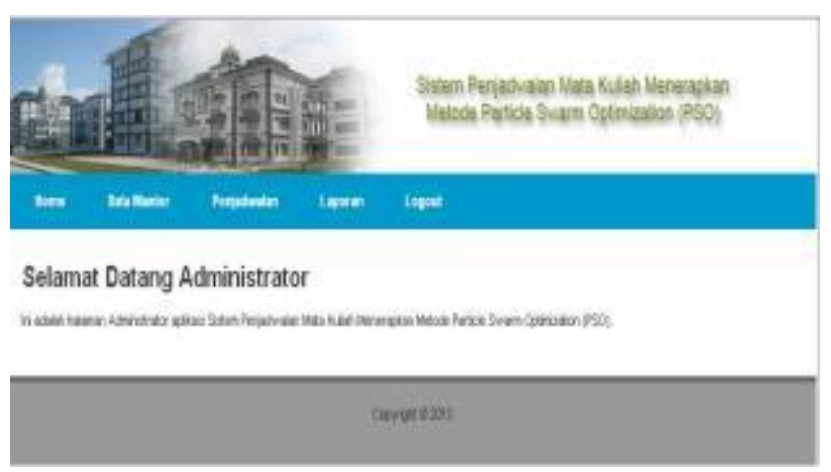

Gambar 5. Tampilan menu utama
Proses Penjadwalan

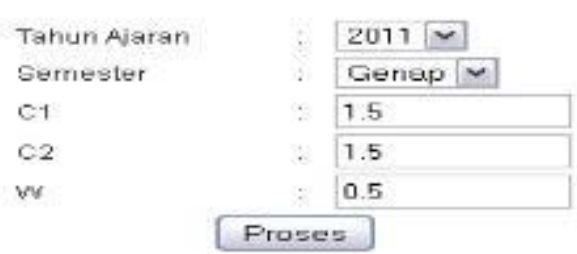

Gambar 6. Proses Pembuatan Jadwal

Setelah menekan tombol "proses", sistem akan memulai proses pembuatan jadwal, nilai setiap iterasi akan disimpan dalam memori sementara. Setelah selesai tekan tombol "Lihat Hasil" untuk melihat data jadwal yang telah dibuat oleh sistem dengan menggunakan PSO.

Untuk menjalankan aplikasi ini, setelah diinputkan data masternya, proses selanjutnya adalah menekan button Penjadwalan, kemudian isi nilai parameter yang dibutuhkan atau bisa menggunakan nilai default. 


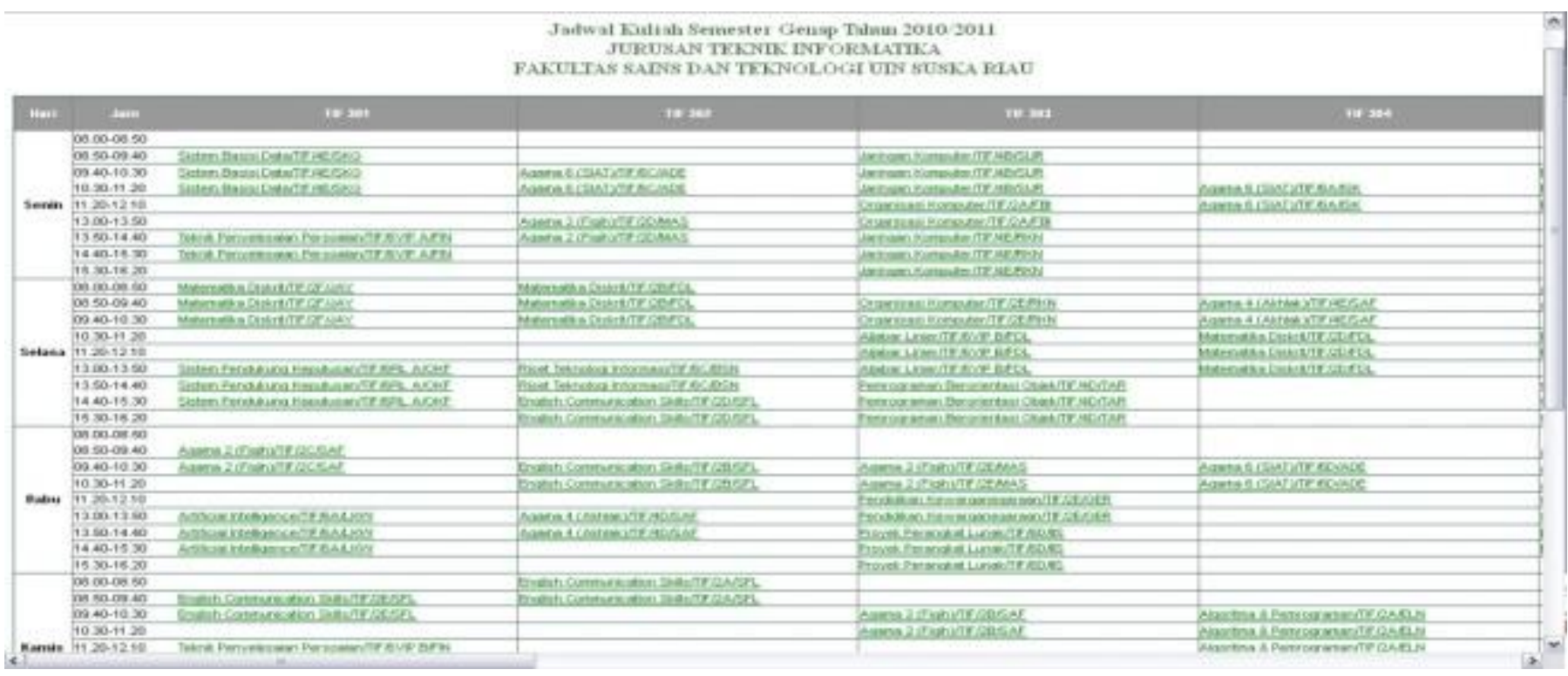

Gambar 7. Laporan jadwal

\subsection{Pengujian} adalah:

Pengujian yang dilakukan pada aplikasi ini

1. Menggunakan Black Box

Hasil pengujian sistem yang dilakukan dengan menggunakan black box adalah:

Tabel 1. Hasil pengujian black box

\begin{tabular}{|c|l|c|}
\hline $\begin{array}{c}\text { No. } \\
\text { Uji }\end{array}$ & \multicolumn{1}{|c|}{ Butir Uji } & $\begin{array}{c}\text { Hasil } \\
\text { Pengujian }\end{array}$ \\
\hline Uji 1 & Pengujian Modul Login & Diterima \\
\hline Uji 2 & $\begin{array}{l}\text { Pengujian Modul Menu } \\
\text { Input Data Hari }\end{array}$ & Diterima \\
\hline Uji 3 & $\begin{array}{l}\text { Pengujian Modul Menu } \\
\text { Input Data Jam }\end{array}$ & Diterima \\
\hline Uji 4 & $\begin{array}{l}\text { Pengujian Modul Menu } \\
\text { Input Data Ruangan }\end{array}$ & Diterima \\
\hline Uji 5 & $\begin{array}{l}\text { Pengujian Modul Menu } \\
\text { Input Data Dosen }\end{array}$ & Diterima \\
\hline Uji 6 & $\begin{array}{l}\text { Pengujian Modul Menu } \\
\text { Input Data Mata Kuliah }\end{array}$ & Diterima \\
\hline Uji 7 & $\begin{array}{l}\text { Pengujian Modul Menu } \\
\text { Input Data Ajar }\end{array}$ & Diterima \\
\hline Uji 8 & $\begin{array}{l}\text { Pengujian Modul Menu } \\
\text { Proses }\end{array}$ & Diterima \\
\hline
\end{tabular}

Berdasarkan pengujian menggunakan Black box, seluruh menu dan button pada sistem penjadwalan perkuliahan ini berfungsi dengan baik.

2. Menggunakan Uji Performansi

Pengujian performansi yang dilakukan dengan pengujian menggunakan parameter nilai default dan parameter inputan user.
Tabel 2. Parameter Perhitungan dengan Nilai Default

\begin{tabular}{|c|c|c|c|}
\hline$C 1$ & $C 2$ & $w$ & $\begin{array}{c}\text { Iterasi } \\
\text { Maksimum }\end{array}$ \\
\hline 1,5 & 1,5 & 0,5 & 1000 \\
\hline
\end{tabular}

Tabel 3. Pengujian Performansi dengan Parameter Nilai Default

\begin{tabular}{|c|c|c|}
\hline Pengujian ke- & Jumlah Iterasi & Hasil Pengujian \\
\hline 1 & 40 & Berhasil \\
\hline 2 & 28 & Berhasil \\
\hline 3 & 32 & Berhasil \\
\hline 4 & 39 & Berhasil \\
\hline 5 & 29 & Berhasil \\
\hline 6 & 37 & Berhasil \\
\hline 7 & 23 & Berhasil \\
\hline 8 & 29 & Berhasil \\
\hline 9 & 45 & Berhasil \\
\hline 10 & 23 & Berhasil \\
\hline
\end{tabular}

Tabel 4. Pengujian Performansi dengan Parameter Input dari

\begin{tabular}{|c|c|c|c|c|c|}
\hline $\begin{array}{c}\text { Pengujian } \\
\text { ke- }\end{array}$ & $\mathrm{C} 1$ & $\mathrm{C} 2$ & $w$ & Iterasi & $\begin{array}{c}\text { Hasil } \\
\text { Pengujian }\end{array}$ \\
\hline 1 & 1 & 2 & 0,6 & 38 & Berhasil \\
\hline 2 & 3 & 2 & 0.6 & 48 & Berhasil \\
\hline 3 & 0.7 & 1.4 & 0.4 & 40 & Berhasil \\
\hline 4 & 3 & 1 & 0.5 & 28 & Berhasil \\
\hline 5 & 2 & 0.5 & 0.9 & 34 & Berhasil \\
\hline 6 & 2 & 1 & 0.8 & 41 & Berhasil \\
\hline 7 & 4 & 1 & 0.5 & 32 & Berhasil \\
\hline 8 & 1 & 4 & 0.5 & 37 & Berhasil \\
\hline 9 & 5 & 1 & 0.4 & 31 & Berhasil \\
\hline 10 & 1 & 7 & 0.7 & 42 & Berhasil \\
\hline
\end{tabular}

Berdasarkan pengujian performansi, baik yang menggunakan parameter nilai default maupun yang menggunakan nilai inputan dari user, sistem ini 
berhasil menghasilkan solusi penjadwalan mata kuliah yang sudah tidak terdapat bentrok terhadap hari, jam, dan ruangan perkuliahan.

\section{Menggunakan User Acceptence Test}

User Acceptance Test merupakan pengujian yang dilakukan dengan meminta persetujuan dari user terhadap output yang dihasilkan oleh aplikasi penjadwalan mata kuliah ini. Responden yang melakukan pengujian yaitu Ketua Jurusan atau Sekretaris Jurusan Teknik Informatika UIN Suska Riau. Hasil pengujian ini adalah: aplikasi ini berhasil menghasilkan jadwal perkuliahan yang sudah tidak terdapat bentrok, namun tidak berhasil memenuhi dari segi kualitas yaitu jam dimulainya perkuliahan yang difokuskan pada jam-jam yang efektif.

\section{PENUTUP}

\subsection{Kesimpulan} berikut:

Kesimpulan dari penelitian ini adalah sebagai

1. Aplikasi penjadwalan mata kuliah menggunakan Particle Swarm Optimization (PSO) berhasil dirancang dan dibangun untuk menghasilkan jadwal perkuliahan di Jurusan Teknik Informatika UIN Suska Riau walaupun tidak semua constraint yang ditetapkan oleh pihak Jurusan terpenuhi.

2. Walaupun berhasil menghasilkan jadwal perkuliahan yang sudah tidak terdapat bentrok, namun tidak berhasil memenuhi dari segi kualitas yaitu jam dimulainya perkuliahan yang difokuskan pada jam-jam yang efektif.
3. Aplikasi penjadwalan mata kuliah ini mampu menangani proses input data, melakukan proses pembuatan jadwal perkuliahan secara otomatis dan menghasilkan jadwal yang dapat ditampilkan dan dapat pula dicetak.

4. Aplikasi penjadwalan mata kuliah menggunakan Particle Swarm Optimization (PSO) memiliki kekurangan yaitu constraint yang tidak bisa berubah sesuai kondisi.

\subsection{Saran}

Dari hasil pembahasan yang telah dilakukan, dapat disarankan untuk penelitian selanjutnya agar:

1. Penelitian mengenai performansi algoritma masih sangat dibutuhkan lebih lanjut pada bidang aplikasi lainnya, sehingga mampu memberikan kontribusi pada perkembangan algoritma tersebut.

2. Untuk pengembangan selanjutnya, constraint dibuat dapat diubah sesuai kebutuhan dan persyaratan pembuatan jadwal yang berlaku.

3. Jam dimulainya perkuliahan difokuskan pada jam-jam yang efektif.

\section{DAFTAR PUSTAKA}

[1] Ariani, Dian, 2011, Optimasi Penjadwalan Mata Kuliah di Jurusan Teknik Informatika PENS Dengan Menggunakan Algoritma Particle Swarm Optimization (PSO), Surabaya, Institut Teknologi Sepuluh Nopember.

[2] Putra, Yendrika, 2009, Aplikasi Penjadwalan Perkuliahan Menggunakan Algoritma Genetika, Pekanbaru UIN Suska Riau

[3] Santosa, Budi, dan Paul Willy, 2011, Metoda Metaheuristik Konsep dan Implementasi, Surabaya, Guna Widya.

[4] Suyanto, 2008, Evolutionary Computation, Bandung, Informatika. 